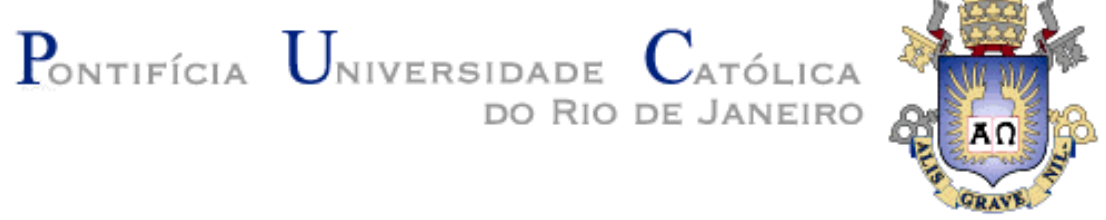

Eduardo Humberto Achá Navarro

\title{
Bamboo: High Tech Material for Concrete Reinforcement
}

\section{TESE DE DOUTORADO}

Thesis presented to the Programa de PósGraduação em Engenharia Civil of the Departamento de Engenharia Civil, PUC-Rio as partial fulfillment of the requirements for the degree of Doutor em Engenharia Civil.

Advisor: Prof. Khosrow Ghavami

Rio de Janeiro

June 2011 


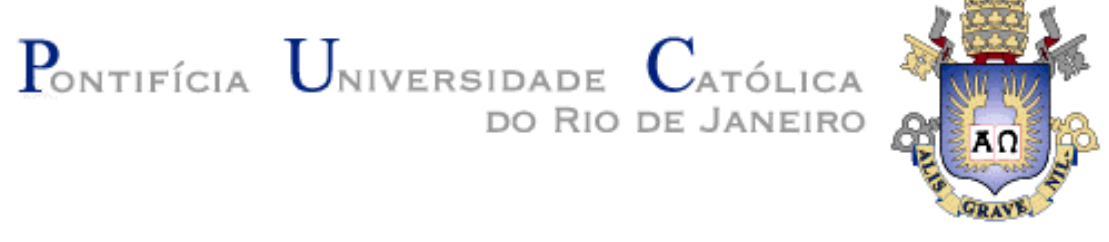

Eduardo Humberto Achá Navarro

\section{Bamboo: High Tech Material for Concrete} Reinforcement

\section{TESE DE DOUTORADO}

Thesis presented to the Programa de Pós-Graduação em Engenharia Civil of the Departamento de Engenharia Civil do Centro Técnico Científico da PUC-Rio, as partial fulfillment of the requirements for the degree of Doutor.

Prof. Khosrow Ghavami Advisor Departamento de Engenharia Civil - PUC-Rio

Prof. Jim Platts Departament of Engineering - University of Cambridge

Prof. Sergio Neves Monteiro Departamento de Engenharia de Materiais - UENF

Prof. Normando Perazzo Barbosa Departamento de Engenharia Civil - UFPB

Prof. Luis Eustáquio Moreira Departamento de Engenharia Civil - UFMG

Prof. Deane de Mesquita Roehl Departamento de Engenharia Civil - PUC-Rio

Prof. José Eugenio Leal Coordinator of the Centro Técnico Científico da PUC-Rio 
All rights reserved

\section{Eduardo Humberto Achá Navarro}

The author is graduated in Civil Engineering at Federal University of Sao Carlos-SP (UFSCar-1999), specialized in structures systems. He got his MSc at Pontifical Catholic University of Rio de Janeiro (PUC-Rio-2002), studying Bamboo Permanent Shutter Concrete Slab. Previously his PhD studies, Eduardo has worked developing a computational routing for long-term test of structural elements on the "Intelligent Concrete" project at Imperial College London (2003) and on the experimental polyester tensile test to temperature time prediction method for floating platforms at University of Cambridge (2004). He is a consulter in the numerical analyses of hydroelectric structures and research member of Nonconventional Materials and Technologies group (NOCMAT). The author has developed this thesis at PUC-Rio, University of Cambridge and University of Bath

Bibliographic data

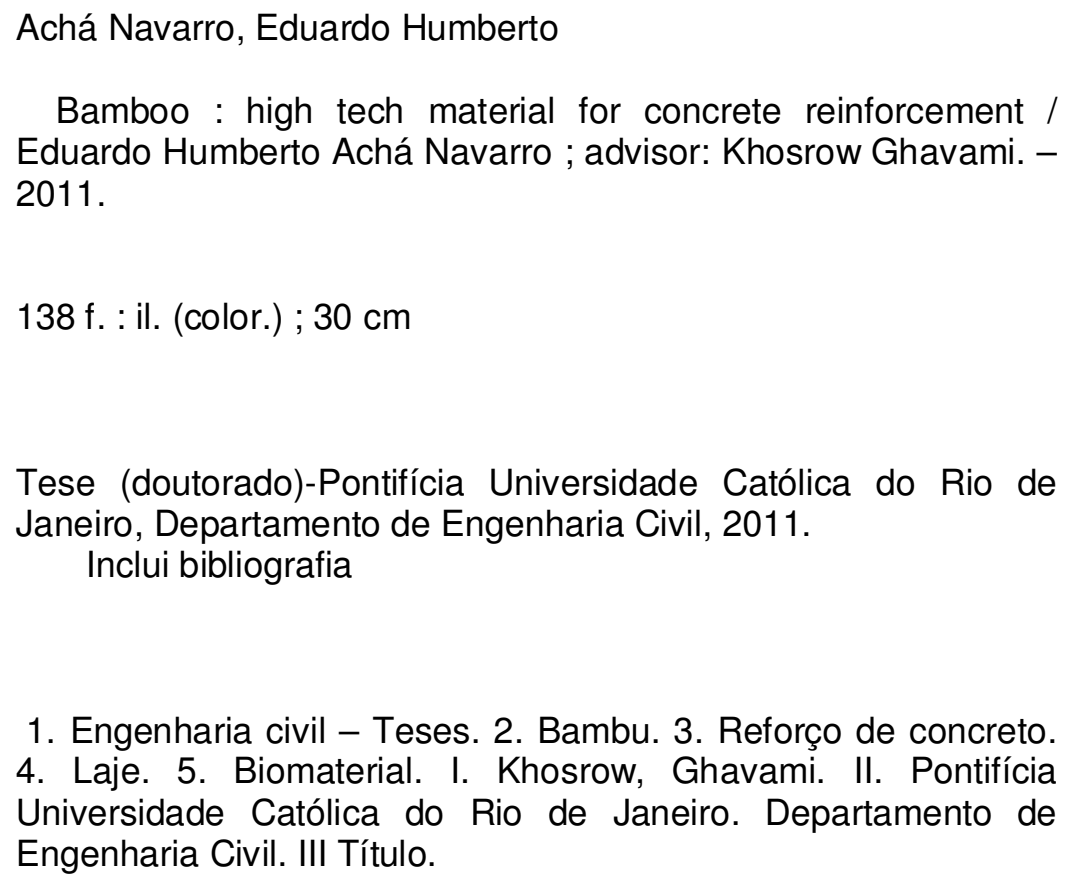
Eduardo Humberto Achá Navarro ; advisor: Khosrow Ghavami. 2011.

138 f. : il. (color.) ; $30 \mathrm{~cm}$

Tese (doutorado)-Pontifícia Universidade Católica do Rio de Janeiro, Departamento de Engenharia Civil, 2011. Inclui bibliografia

1. Engenharia civil - Teses. 2. Bambu. 3. Reforço de concreto. 4. Laje. 5. Biomaterial. I. Khosrow, Ghavami. II. Pontifícia Universidade Católica do Rio de Janeiro. Departamento de Engenharia Civil. III Título.

CDD: 624 
To my silence 


\section{ACKNOWLEDGEMENTS}

To all of my family for the education, orientation and love.

To my father Eduardo Achá Casas who showed me how to respect and never forget the people that never had the opportunity in education that I had.

To my mother Rosario Navarro Avila who showed me how to believe and follow my dreams with energy.

To my brothers Ingrid and Carlos for the love shown and the happiness given to me by them in my live.

Many thanks to Prof. Khosrow Ghavami for his patience, friendship and support in the development of this work, and my grateful thanks for how he taught me to research natural materials and enabled me to be more connected to nature.

To Eng. Mohy Camel for his support in this work and interest in new alternative solutions in engineering.

To Jenny Hornett from IFM - University of Cambridge for her friendship, help in the editing of this work and interesting conversations.

To my friends Paulo Arauz, Antonio Pellisari, Joabson Alves, Andreia Laplana, Diego Marquez, Diego Alcala, Marcelo Alcala, Jan Janulewicz, Carla da Costa, Fernanda Mello, Eduardo Pasquete and Maurizio Tomasella for their help and friendship.

To the technicians of the Civil Engineering Structure Lab at PUC-Rio, University of Cambridge and University of Bath.

Many thanks to Dr. Jim Platts and Prof. Peter Walker for their assistance at the University of Cambridge and University of Bath.

All my friends from the Pontifical Catholic University of Rio de Janeiro, University of Cambridge and University of Bath are also gratefully acknowledged.

The author would like to thank the "Coordenação de Aperfeiçoamento de Pessoal de Nível Superior" (CAPES) and MEK Engineering and consultant for their economic support of this research program. 


\section{Abstract}

Acha Navarro, Eduardo Humberto; Ghavami, Khosrow (Advisor). Bamboo: High Tech Material for Concrete Reinforcement. Rio de Janeiro, 2011. 138p. Dr. Thesis-Departamento de Engenharia Civil, Pontificia Universdade Catolica do Rio de Janeiro.

In this study, based on the results of bamboo surface treatment for concrete reinforcement developed at PUC-Rio (Brazil), theoretical and experimental analyses were executed at the University of Cambridge and University of Bath (England). To improve the bamboo surface treatment (using epoxy resin) an experimental program concerning 32 push-out specimens were carried out. Bamboo strips (for reinforcing concrete) prepared from Phyllostachys Pubescens bamboo and treated to enhance surface bonding were used, with a constant embedment length of $20 \mathrm{~mm}$. The influence of two resins type, gravel size ( 2 or 4 $\mathrm{mm}$ ), bamboo node and procedures for cleaning the surface of the bamboo on the bond-slip curves obtained are analyzed. Using the best bamboo surface treatment a full scale (3000 mm by $3000 \mathrm{~mm}$ ) two-way spanning concrete slab reinforced with bamboo strips (without any shear reinforcement) was constructed and tested. The experimental test was simply supported along its four sides and subjected to a central concentrated load. A finite element model was created using SAP2000 to analyse and design the bamboo reinforcement. Experimental failure load was found to be approximately $148.39 \%$ and $110.91 \%$ of the theoretically predicted values by the numerical model and by ultimate punching shear load (following BS 8110 [36]) respectability. The slabs exhibited high stiffness against deformation prior to collapse through punching shear load. Finally, to produce an advanced bamboo composite material for concrete reinforcement, an experimental investigation of the effect of moisture content at room temperature and frozen conditions on Bamboo Dendrocalamus giganteus $(D G)$ layers with highest fibre volume fraction $\left(\mathrm{V}_{\mathrm{f}}\right)$ were considered. 2250 tensile and compression test specimens were tested. The absorption of water, mechanical properties of bamboo layers and failure were analyzed in detail and appropriate mathematical equations have been established. From the results the tensile strength and tensile modulus of elasticity (TMOE) of DG bamboo fibres were estimated. The results show that 
Dendrocalamus giganteus $(D G)$ bamboo layers with highest fibres volume fraction $\left(\mathrm{V}_{\mathrm{f}}\right)$ and low moisture content can be applied in composite materials for construction, energy field (structural parts of wind turbine blades), automotive field (car structures), and aviation (small aircraft) providing a new low carbon alternative material.

\section{Keywords}

Bamboo; Concrete reinforcement; slabs; Biomaterials 


\section{Resumo}

Acha Navarro, Eduardo Humberto; Ghavami, Khosrow (Advisor). Bambu: Material "High Tech" como Reforco em Concreto. Rio de Janeiro, 2011. 138p. Dr. Tese -Departamento de Engenharia Civil, Pontificia Universdade Catolica do Rio de Janeiro.

Em este estudo, com base nos resultados do tratamento da superfície do bambu para reforço de concreto desenvolvido na PUC-Rio (Brasil), análises teóricas e experimentais foram executados na University of Cambridge e University of Bath (Inglaterra). Para melhorar o tratamento da superfície do bambu (usando resina epóxi), um programa experimental sobre 32 espécimes de Push-out foram realizadas. Tiras de bambu (para concreto armado) preparadas a partir de bambu Phyllostachys pubescens e tratados para melhorar a aderência foram utilizados, com um comprimento embutido de $20 \mathrm{~mm}$. A influência do tipo de resina, tamanho do agregado (2 $\mathrm{mm}$ ou $4 \mathrm{~mm}$ ), nó do bambu e os procedimentos para limpar a sua superfície foram obtidas é analisadas em curvas de aderência-deslizamento. Usando o tratamento com melhores resultados uma laje de concreto (3000 mm x $3000 \mathrm{~mm}$ ) reforçada nas duas direções com tiras de bambu (sem armadura de cisalhamento) foi construída e testada. A laje foi testada simplesmente apoiada nos quatro lados com carga concentrada no meio. Um modelo de elementos finitos (MEF) foi criado usando SAP2000 para analisar e projetar o reforço de bambu. A carga experimental de colapso foi aproximadamente $148,39 \%$ e $110,91 \%$ dos valores teoricamente previstos pelo modelo numérico e pela carga máxima de punção (seguindo BS 8110 [36]) respeitabilidade. A laje apresentou alta rigidez contra a deformação antes do colapso por punção. Finalmente, para produzir um material composto avançado usando bambu para reforço de concreto, investigações experimentais do efeito do teor de umidade à temperatura ambiente e em condições de congelamento do bambu Dendrocalamus giganteus ( $D G$ ) foram realizadas. Laminas de bambu com maior fração volumétrica de fibras (Vf) foram consideradas. 2250 corpos de prova de tração e compressão foram testados. A absorção de água, propriedades mecânicas das laminas de bambu e colapsos foram analisados em detalhe, e adequadas equações matemáticas foram estabelecidas. A partir dos resultados da 
resistência e módulo de elasticidade à tração (TMOE) da fibra de bambu DG foram estimados. Os resultados mostraram que as laminas de Dendrocalamus giganteus $(D G)$ com maior fração volumétrica de fibras (Vf) e baixa umidade podem ser aplicadas em materiais compósitos para a construção, campo de energia (peças estruturais das hastes de turbinas eólicas), área automotiva (estruturas de carros), e aeronáutica (aviões de pequeno porte), fornecendo um novo material alternativo de baixo consumo de carbono.

\section{Palavras-chave}

Bambu; reforço para concreto;lajes; biomateriais 


\section{Contens}

$\begin{array}{ll}\text { 1. Introduction } & 21\end{array}$

2.Literature review 25

2.1. General introduction to bamboo 25

2.2. Bamboo Chemical Composition 25

2.3. Properties of Bamboo 26

2.3.1. Anatomical structure 26

2.3.2. Physical and Mechanical Properties 27

2.4. Bamboo as concrete reinforcement 30

2.5. Punching shear strength $\quad 35$

2.6. Final considerations 36

3. Bond characteristics of treated bamboo strips embedded in concrete 38

3.1. Introduction 38

3.2. Experimental program 39

3.2.1. Materials 39

3.2.2. Specimens, setup and testing equipment 41

3.3. Experimental results 42

3.3.1. Bond strength 42

3.3.1.1. Effect of concrete strength on bond strength 44

3.3.1.2 Effect of resin type on bond strength 44

3.3.1.3. Effect of surface treatments on bond strength 45

3.3.2. Bond stress-slip relationship 46

3.3.3. Initial bond stiffness 53

3.4. Conclusions $\quad 54$

4. Theoretical and experimental analysis of full scale two-way concreteslab reinforced with bamboo strips 
4.1. Introduction

4.2. Experimental programme 56

4.2.1. Materials 56

4.2.2. Specimen details 59

4.2.3. Instrumentation and casting $\quad 67$

4.2.4. Test procedure $\quad 70$

4.3. Theory 70

4.3.1. Flexural theory $\quad 70$

$\begin{array}{ll}\text { 4.3.2. Punching shear strength } & 71\end{array}$

4.4. Theoretical and experimental results 71

4.4.1. Material properties of slabs 71

4.4.2. Behaviour of two-way slab 71

4.5. Discussion of test results 72

4.5.1. Mode of failure $\quad 72$

4.5.2. Load-deflection curves $\quad 75$

4.5.3. Load-bamboo strain curves 79

4.5.4. Effect of cyclic loading 83

4.6. Conclusions 83

5. Effect of moisture contents at room temperature and frozen conditions on the mechanical properties of Dendrocalamus giganteus (DG) bamboo

5.1. Introduction

5.2. Tensile properties $\quad 87$

5.2.1. Experimental approach 87

5.2.2. Experimental details 87

5.2.3. Fibre volume fraction $\left(\mathrm{V}_{\mathrm{f}}\right)$ measurements 88

5.2.3. Results and discussion 90

5.2.3.1. Moisture absorption 90

5.2.3.2. Moisture content effects on tensile stress-strain 91

5.2.3.3. Moisture content effects on tensile modulus of elasticity(TMOE) 93

5.2.3.4. Moisture content effects on tensile stress 95 
5.2.3.5. Effect of frozen moisture on tensile stress

5.2.3.6. Fibre tensile strength and TMOE

estimation

100

5.2.3.7. Tensile failure

104

5.3. Compression properties

105

5.3.1. Experimental approach

105

5.3.2. Experimental details

106

5.3.3. Results and discussion

107

5.3.3.1. Moisture content effects on compression stress-strain

107

5.3.3.2. Moisture content effects on compression stress

110

5.3.3.3. Effect of frozen moisture on compression stress

5.3.3.4. Compression failure

115

5.4. Conclusion

116

6. Conclusion and recommendation for further work

6.1. Conclusion

6.2. Recommendation for further work

120

7. Bibliogrady

121

Appendix I

128 


\section{List of figures}

Figure 2.1- Transverse section of Dendrocalamus giganteus (DG) bamboo showing a decreasing distribution density of vascular bundles from the outer layer to inner layer of the culm wall

Figure 2.2- Moisture content of three years old bamboo of different internodes [43]

Figure 2.3- A material property chart for natural materials, plotting Young's modulus against density [7]

Figure 2.4- (a) formwork of BTDG-HDC (b) formwork of BTDG-FDC (c) epoxy resin treatment [35]

Figure 2.5 - SIKADUR 32 GEL+Brita Surface treatment scheme

Figure 2.6 - Full scale two-way concrete slab reinforced with bamboo strips scheme

Figure 3.1- Bamboo strips surface treatments 39

Figure 3.2- (a) Specimen's dimensions (b) Push-out test set up 41

Figure 3.3- Specimen identification description 42

Figure 3.4- (a) $T_{\max }$ for specimens when using epoxy

or polyester resin (b) $T_{\max }$ increase ratio due to change of resin

Figure 3.5- Specimens bond stress-slip curves

for (a) 2-E/N-N and (b) 2-P/N-N groups

Figure 3.6- Specimens bond stress-slip curves for

(a) 2-E/N-C and (b)2-P/N-C groups

Figure 3.7- Specimens bond stress-slip curves for

(a) $4-\mathrm{E} / \mathrm{N}-\mathrm{C}$ and (b) $4-\mathrm{P} / \mathrm{N}-\mathrm{C}$ groups

Figure 3.8- Specimens bond stress-slip curves for

(a) 2-E/K-C and (b)2-P/K-C groups

Figure 3.9- Examples of failure modes: (a) peeling off of natural (not cleaned) strip surface; (b) peeling off of cleaned strip surface;

(c) peeling off and push-out of strip with node and cleaned 
Figure 3.10- Influence of type of bamboo strip surface treatment on the initial stiffness. Bond stress- slip curves of N-N, N-C and $\mathrm{K}-\mathrm{C}$

Figure 4.1- Simply supported slab and central concentrated load test (layout)

Figure 4.2- (a) Metallic blades to split the bamboo culm section (b) blades positioned on a steel beam (c-d) split force registration (e-f) bamboo splitter procedure

Figure 4.3- (a) Cleaning bamboo strips (b) painting surface with epoxy resin (c) coating bamboo strip with $2 \mathrm{~mm}$ aggregate (d) Dry treated bamboo strips

Figure 4.4- (a) Slab's bottom face before testing (b) Scheme of the Influence of the bamboo strip cross section in casting

Figure 4.5- SAP2000's tension analysis for design bamboo reinforcement considering $98 \mathrm{KN}$ centred load (KN,m)

Figure 4.6- (a) DELCAR's results for bamboo reinforcement (b) Bamboo reinforcement adopted

Figure 4.7- (a) Geometrical distribution of bamboo strips on the mesh (b) bamboo mesh ready before casting

Figure 4.8- (a-b) Strain gages instrumentation (c-e) Casting

of slab (f) LVDT instrumentation

Figure 4.9- Test's loading procedure

Figure 4.10- (a) Slab's crack pattern observed underneath

(b) punching mode failure (c) no concrete crushing on failure

Figure 4.11- Analysis of bamboo strips surface treatment (gravel coating) after test

Figure 4.12- Load-deflection curves 78

Figure 4.13- Load-bamboo strain curves

Figure 5.1- (a) Transverse section of Dendrocalamus giganteus (DG) bamboo showing a decreasing distribution density of vascular bundles from the external to internal surface and the components of the culm wall (along the radial direction) (b) vascular bundle 
Figure 5.2- (a) Tensile test (b) bamboo specimen dimension

Figure 5.3- Images used for definitions of fibre volume

fraction $\left(V_{f}\right)(a-c)$ areas of the first, second and third $2 \mathrm{~mm}$ layers from the external to internal surface bamboo culm where the corresponding values of $V_{f}$ were $57.4 \%, 52.3 \%$ and $47.4 \%$ respectively

Figure 5.4-Moisture contents of the first, second and third $2 \mathrm{~mm}$ layer $\left(\mathrm{V}_{\mathrm{f}}, 57.4 \%, 52.3 \%\right.$ and $47.4 \%$ respectively) from the external to the internal surface of the DG bamboo culm

Figure 5.5- Tensile stress-strain curves for samples containing $V_{f}$ (a) $57.4 \%$ (b) $52.3 \%$ and (c) $47.4 \%$ at moisture content between $2 \%$ and $85 \%$

Figure 5.6- Tensile modulus of elasticity-moisture content curves for samples containing $V_{f} 57.4 \%, 52.3 \%$ and $47.4 \%$ at moisture content between $2 \%$ and $85 \%$

Figure 5.7- Tensile stress-moisture content curves for samples containing (a) $V_{f} 57.4 \%$ (b) $52.3 \%$ and (c) $47.4 \%$ at plain and frozen moisture content between $2 \%$ and $85 \%$

Figure 5.8- Relationship between (a) fibre volume fraction $\left(\mathrm{V}_{\mathrm{f}}\right)$ and bamboo tensile strength and $(\mathrm{b})$ TMOE

Figure 5.9- Typical tensile fracture of: (a-c) 3 specimens with different $V_{f}$ and moisture content below $7 \%$ and $(d)$ specimens with moisture content over $7 \%$

Figure 5.10- (a) Compression test (b) bamboo specimen dimension

Figure 5.11- Compression stress-strain curves for samples containing $V_{f} 57.4 \%$ (a) $52.3 \%$ (b) and $47.4 \%$ (c) at moisture content between $2 \%$ and $85 \%$

Figure 5.12- Maximum compressive stress-moisture content curves for samples containing $V_{f} 57.4 \%$ (a) $52.3 \%$ (b) and $47.4 \%$ (c) at plain and frozen moisture content between $2 \%$ and $85 \%$

Figure 5.13-Typical compression failure of: (a-c) 3 specimens with different $V_{f}$ and moisture content below $5 \%$ (d) specimens with moisture content over $5 \%$ 
Figure Al.1- Usual cross section in (a) power houses (c) intakes and ( $b$ and $d)$ a statistical study of thickness and main span of floor slab at power houses 128

Figure A.I.2- Basic concept due the increment of cross section 129 


\section{List of tables}

Table 2.1- Compression strength of bamboo [43] 28

Table 2.2- Bamboo-concrete push-out test results, presented by Culzoni (1986)[31] and obtained result using SIKADUR $32 \mathrm{Gel}$ (Achá, 2002)[35] 32

Table 2.3- Materials properties [35] 33

Table 2.4- Analytical results (Acha, 2002) [35] 34

Table 3.1- Surface treatment, Geometrical and mechanical properties of bamboo strips 39

Table 3.2- Concrete mix 40

Table 3.3- Experimental results 43

Table 4.1- Experimental and theoretical result loads

72

Table 4.2- Deflection of slab and strain on bamboo strips at service load, state limit of use and ultimate load 82

Table 5.1- Average results of tensile test 101

Table 5.2- Average results of compression test 114

Table Al.1- Reinforcement required 130

Table Al.2- Reinforcement required 130

Table Al.3- Reinforcement required 131

Table Al.4- Reinforcement required 131

Table Al.5- Reinforcement required 132

Table Al.6- Reinforcement required 133

Table Al.7- Reinforcement required 133

Table Al.8- Reinforcement required 134

Table AI.9- Reinforcement required 135

Table Al.10- Reinforcement required 136

$\begin{array}{ll}\text { Table Al.11- Reinforcement required } & 137\end{array}$

Table Al.12- Reinforcement required 137

$\begin{array}{ll}\text { Table Al.13- Reinforcement required } & 138\end{array}$ 


\section{List of symbols and abbreviation}

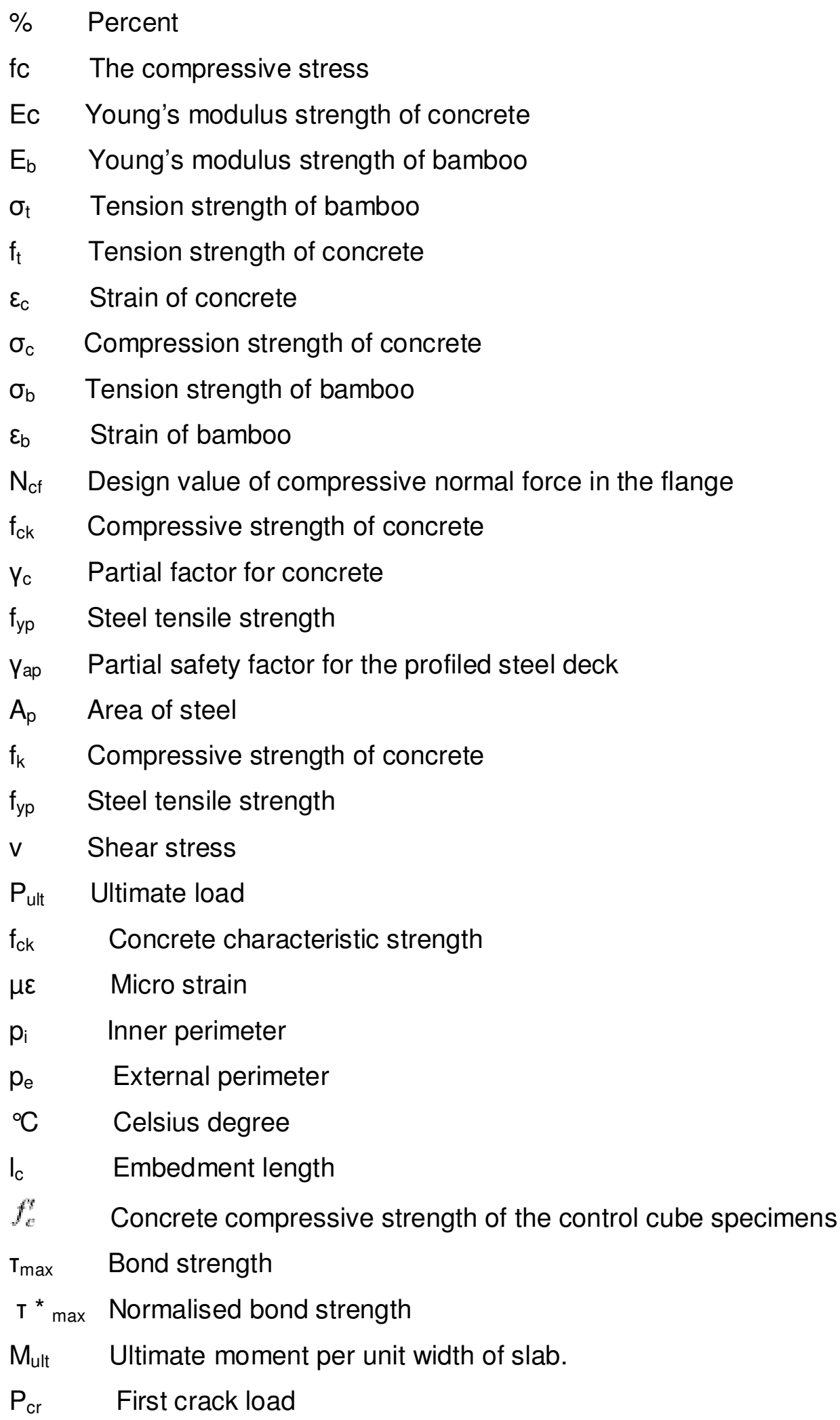




$\begin{array}{ll}\mathrm{P}_{\mathrm{ul}} & \text { Failure load } \\ \mathrm{P}_{\mathrm{cr}} & \text { First theoretical crack load } \\ \% \circ & \text { Per thousand } \\ \delta & \text { Vertical deflection } \\ q & \text { Distributed load } \\ \mathrm{V}_{f} & \text { Fibre volume fraction } \\ A_{f} & \text { Area of fibres } \\ A_{l} & \text { Walls cross-section were measured } \\ \mathrm{M}_{\mathrm{c}} & \text { Moisture content } \\ \sigma_{\mathrm{TE}} & \text { Tensile strength at the elastic region } \\ \text { TMOE } & \text { Tensile modulus of elasticity }\end{array}$


People are illogical, unreasonable, and self-centered.

Love them anyway.

If you do good, people will accuse you of selfish ulterior motives.

Do good anyway.

If you are successful, you win false friends and true enemies.

Succeed anyway.

The good you do today will be forgotten tomorrow.

Do good anyway.

Honesty and frankness make you vulnerable.

Be honest and frank anyway.

The biggest men and women with the biggest ideas can be shot down by the smallest men and women with the smallest minds.

Think big anyway.

People favor underdogs but follow only top dogs.

Fight for a few underdogs anyway.

What you spend years building may be destroyed overnight.

Build anyway.

People really need help but may attack you if you do help them.

Help people anyway.

Give the world the best you have and you'll get kicked in the teeth.

Give the world the best you have anyway.

by Dr. Kent M. Keith

In the final analysis, it is between you and your God. It was never between you and them anyway.

by Mother Teresa 